\title{
Bloom inside the bloom: intracellular bacteria multiplication within toxic dinoflagellates
}

\author{
Florecimiento dentro de un florecimiento: multiplicación de las bacterias intracelulares de \\ dinoflagelados tóxicos
}

José L. Córdova, Claudia Escudero and Juana Bustamante

Fundación Ciencia para la Vida and the Millennium Institute for Fundamental and Applied Biology, Av. Marathón 1943, Ñuñoa, Santiago, Chile

jcordova@bionova.cl

\begin{abstract}
This study has shown that Alexandrium catenella and Protoceratium reticulatum are infected with different species of bacteria. Using 5-cyano-2,3-di-4-tolyltetrazolium chloride (CTC), a substrate that becomes fluorescent after being reduced by electrons produced during bacterial respiration and combined with confocal microscopy analysis, live intracellular bacteria were observed. It was possible to determine that these dinoflagellates had a heavier bacterial load when the culture was in stationary phase as compared to the log phase. We have termed this observation "bloom inside the bloom". Whether the high number of intracellular bacteria observed is a result of intracellular bacteria multiplication or re-infection from broken cells with heavy bacterial infection is unknown. Additionally, the bacteria isolates from each dinoflagellate are capable to reinfect both dinoflagellates regardless of their origin. Furthermore, when sodium nitrate and sodium phosphate are supplemented into the culture medium the bacterial multiplication pattern in both dinoflagellates is modified. Finally, based on this study, we propose the hypothesis that the interaction between intracellular bacteria and dinoflagellate is bimodal: at the beginning of the growth curve is mutualistic and at later stages, bacteria become parasitic, killing the host cell. This hypothesis could explain the suddenly disappearance of blooms in nature, without excluding other factors.
\end{abstract}

Key words: Interaction dinoflagellate-bacteria, intracellular bacteria multiplication, bacterial infection, Alexandrium catenella, Protoceratium reticulatum

\section{Introduction}

The symbiotic relationship between bacteria and toxic dinoflagellates that causes Harmful Algal Blooms (HAB, was first described by Silva (1962, 1982), who suggested that bacteria may be involved in toxin production. Subsequently, Kodama et al., (1988) and Franca et al. (1995), reported on the isolation of toxic
Resumen.- La presente investigación muestra que Alexandrium catenella y Protoceratium reticulatum están infectados con diferentes especies de bacteria. Empleando el 5ciano-2,3-di-4-tolil-cloruro de tetrazolium (CTC), substrato enzimático que se vuelve fluorescente después de ser reducido por los electrones que se producen durante la respiración bacteriana y combinado con un análisis empleando el microscopio confocal, se pudo observar bacterias intracelulares vivas. Fue posible determinar que estos dinoflagelados tienen una gran infección bacteriana cuando el cultivo está en su fase estacionaria al ser comparado con el cultivo en fase logarítmica. A esta observación la hemos denominado "florecimiento dentro de un florecimiento". Sin embargo, si el gran número de bacterias observadas es solamente producto de la multiplicación de las bacterias intracelulares o re-infección con bacterias de células rotas con alta infección bacteriana, está por esclarecerse. También hemos demostrado que las bacterias intracelulares de cada dinoflagelado son capaces de re-infectar cualquier dinoflagelado, independientemente de su origen. Además, cuando el medio de cultivo fue suplementado con nitrato de sodio o fosfato de sodio, el patrón de multiplicación intracelular bacteriano fue modificado.

Finalmente, basados en nuestros resultados, proponemos la hipótesis de que la interrelación entre la bacteria intracelular y el dinoflagelado es bimodal: durante la fase logarítmica de cultivo es mutualista, mientras que en la fase estacionaria se vuelve parasitaria terminando con la muerte del dinoflagelado. Esta hipótesis permite explicar la desaparición rápida de los florecimientos en la naturaleza, sin excluir la participación de otros factores.

Palabras clave: Interacción dinoflagelado-bacteria, multiplicación intracelular de bacteria, infección bacteriana, Alexandrium catenella, Protoceratium reticulatum bacteria from different dinoflagellates and the presence of bacteria within dinoflagellates has been established (Lewis et al. 2001; Córdova et al. 2002; Biegala et al., 2002). Several additional aspects related to this interaction have been reported. These include autonomous toxin production (Tamplin 1990; Gallacher et al. 1997); the indication of bacteria capable of metabolizing toxins (Kotaki et al. 1985; Doucette et al. 


\section{Alexandrium catenella}
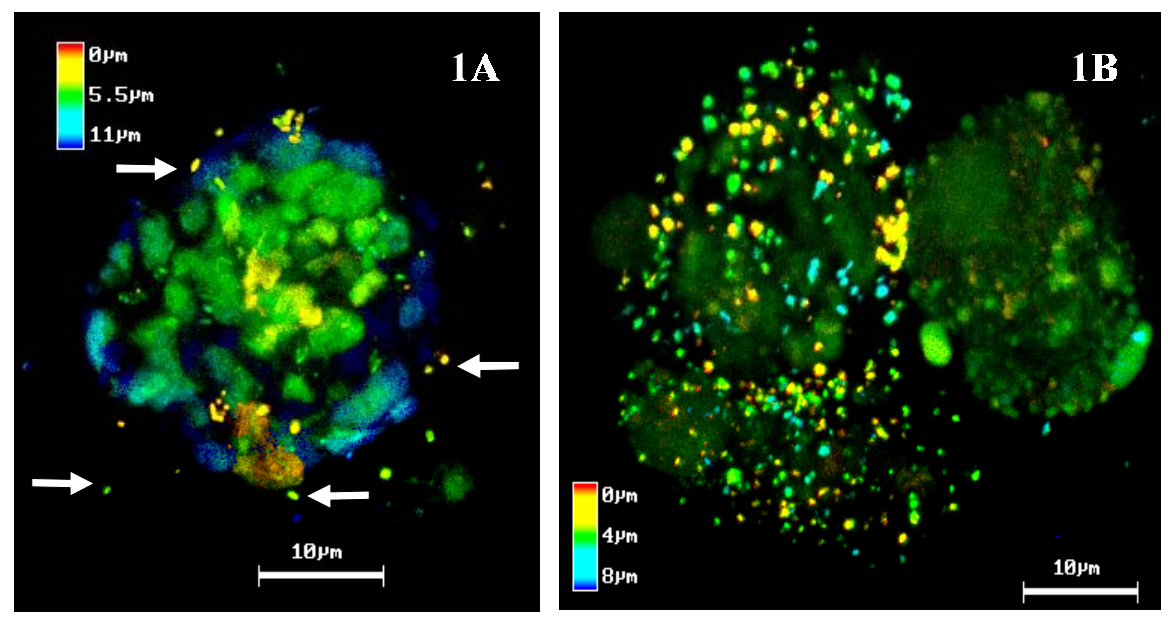

\section{Protoceratium reticulatum}
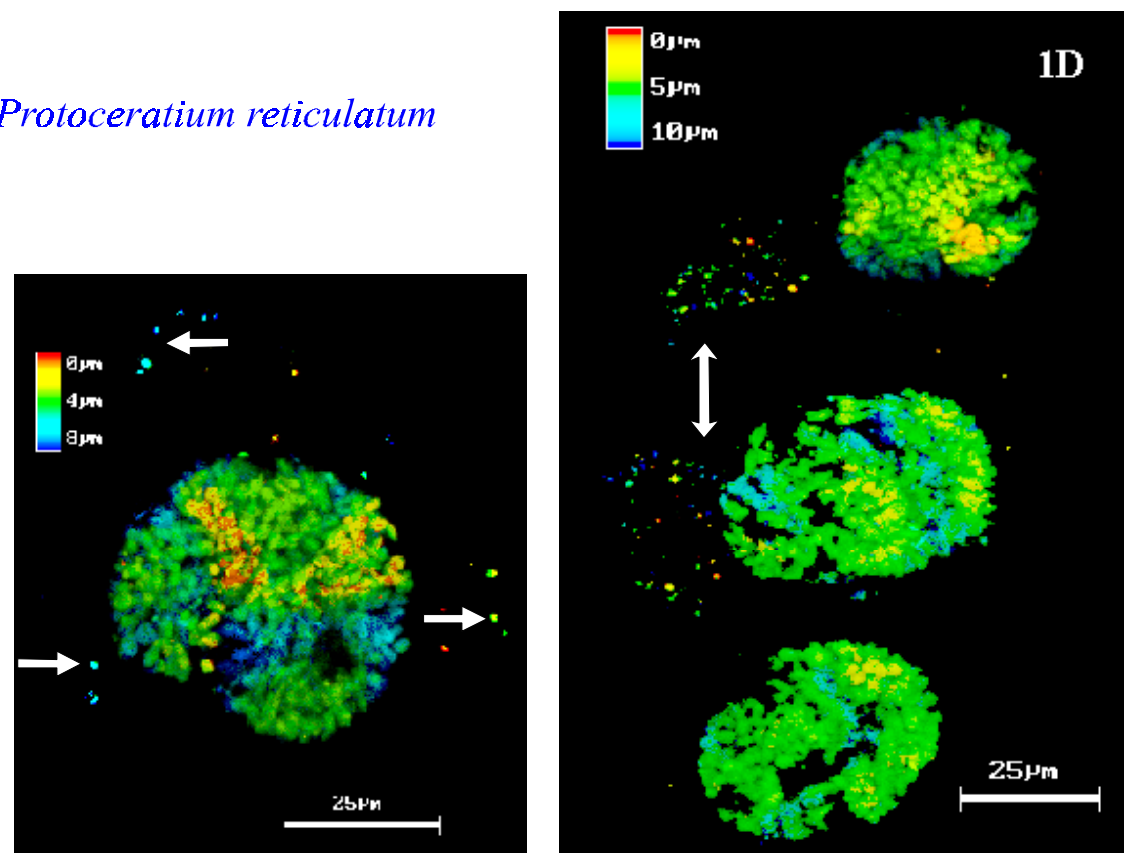

Figure 1

Detection of intracellular bacteria. Dinoflagellate cells after 1 and 14 days of culture fixed with glutaraldehyde and incubated with CTC. Confocal microscopy analysis was performed as described in Materials and Methods. Intracellular bacteria are visualized as tiny fluorescent dots (arrows), as well as the shape of the bacteria. Figs. 1A and 1B, A. catenella; 1C and 1D, $P$. reticulatum. Colors are given by computer integration of the virtual planes generated by the confocal microscope and given according to the color bar

Detección de bacterias intracelulares. Células de dinoflagelados después de 1 y 14 días de cultivo fijadas con glutaraldehído e incubadas con CTC. El análisis mediante microscopía confocal se realizó como se describe en Materiales y Métodos. Las bacterias intracelulares se visualizaron como pequeños puntos fluorescentes (flechas), los cuales también describen la morfología de la bacteria. $1 \mathrm{~A}$ y $1 \mathrm{~B}$, A. catenella; $1 \mathrm{C}$ y 1D, $P$. reticulatum. Los colores son obtenidos mediante integración computarizada de los planos virtuales generados por la microscopía confocal y dados de acuerdo a la barra de color 
1998, Smith et al. 2002); the effects of bacteria on dinoflagellate mating events (Sawayama et al. 1993) and several direct or indirect influences in microalgae toxin production and survival (Bates et al. 1995; Yoshinaga et al. 1985; Nagai \& Imai 1998). However, these reports do not provide information regarding bacterial behavior inside dinoflagellates.

Recently, using a novel staining technique that allows visualization of intracellular bacteria we demonstrated that intracellular bacteria within Alexandrium catenella were alive and that the dinoflagellate was infected simultaneously by different bacterial species (Córdova et al. 2001) and confirmed by using different probes (Töbe et al. 2003). Using the same technique, we report here that intracellular bacteria multiply independently of dinoflagellate growth, a phenomena that we have named "bloom inside the bloom". This phenomenom was observed in two toxic dinoflagellates, A. catenella and Protoceratium reticulatum. Moreover, isolated bacteria were capable of re-infecting these dinoflagellates regardless of which dinoflagellate species they were isolated from. We have also shown that by supplementing the dinoflagellate growth medium with sodium nitrate and sodium phosphate the bacterial multiplication pattern can be modified.

\section{Materials and Methods}

\section{Dinoflagellate strains and bacterial cultures}

The ASACQ001 clone of Alexandrium catenella was obtained from a cyst isolated from the XI Region of Chile in 1997 and maintained at $10^{\circ} \mathrm{C}$. The Reti-1 Protoceratium reticulatum clone was kindly donated by Dr. Santiago Fraga, IOC-VIGO, Spain, and was cultured at $20^{\circ} \mathrm{C}$. Both species were cultured in $\mathrm{f} / 2$ medium (Guillard 1975) and exposed to permanent daylight. Intracellular bacteria from toxic dinoflagellates were grown using ATCC Medium 1861 broth: Ori medium, prepared in seawater (sterilized by filtration through a $0.22 \mu \mathrm{m}$ membrane). Bacterial cultures were grown without agitation at room temperature.

\section{Bacterial multiplication within dinoflagellates}

Ten ml of a 7-day old cultures of Alexandrium catenella and Protoceratium reticulatum were transferred into a new tube containing $10 \mathrm{ml}$ of fresh $\mathrm{f} / 2$ medium. Twenty four hours later (Day 1), $3 \mathrm{ml}$ of culture were collected, concentrated by centrifugation, the pellet resuspended in $0.5 \mathrm{ml}$ of filtered seawater and fixed with glutaraldehyde at $2 \%(\mathrm{v} / \mathrm{v})$ final concentration for 15 minutes at room temperature. The fixed cultured cells were washed twice with sterile seawater and incubated at $10^{\circ} \mathrm{C}$ for $2 \mathrm{~h}$ under dim light with $1 \mathrm{mg} / \mathrm{ml}$ of 5-cyano2,3-di-4-tolyl-tetrazolium chloride (CTC, Polysciences, Warrington, PA) as described by Córdova et al. (2001). Bacteria inside the cells were visualized and counted using an epifluorescence MC80 Axiscop microscope (Zeiss, Germany). Bacteria from 100 cells of each toxic dinoflagellate were individually counted at 1,7 and 14 days of culture. The number of bacteria per cell was scored and classified arbitrarily into 5 groups: a) negative (no infection) or not detected, b) between 1 and 5 bacteria/cell, c) between 6 and 10, d) between 11 and 20, and e) greater than 21.

In addition, samples from each time point were examined using the Axiovert 135M Confocal Microscope (Zeiss, Germany). Images were processed using the LSM 3.9 program.

\section{Infection of dinoflagellates with isolated bacteria}

Four different intracellular bacteria (identified only by their morphology using Gram stain) previously isolated (Córdova et al. 2002) from Alexandrium catenella cells were grown for $24 \mathrm{~h}$ as described above. One $\mathrm{ml}$ of each culture was pooled and cultured for other additional 24 h. After measuring the culture absorbance (A600 $=0.125$, $\mu \mathrm{v}-160 \mathrm{~A}$ spectrophotometer, Shimatzu, Japan) an aliquot of $1 \mathrm{ml}$ was mixed with $10 \mathrm{ml}$ of a 3-day old $A$. catenella culture and incubated as described above. Culture samples were evaluated 1 day later and processed for CTC staining and analyzed as described above. A similar experiment was done with Protoceratium reticulatum. Cross infection experiments were performed by mixing the four bacterial clones isolated from $A$. catenella with $P$. reticulatum cells and the four bacterial clones isolated from $P$. reticulatum with A. catenella cells, and evaluated as described above.

\section{Intracellular bacterial growth in dinoflagellate nutrient-supplemented medium culture}

An aliquot $(175 \mathrm{ml})$ of a 7 day old culture of Alexandrium catenella was gently mixed and divided into 7 tubes. The first tube was left as control and used to monitor intracellular bacteria multiplication under normal culture conditions. The second and third tubes were supplemented with $5 \mu \mathrm{M}$ and $20 \mu \mathrm{M}$ of sodium phosphate, respectively. The fourth and fifth culture tubes were supplemented with $100 \mu \mathrm{M}$ and $300 \mu \mathrm{M}$ of 
Alexandrium catenella
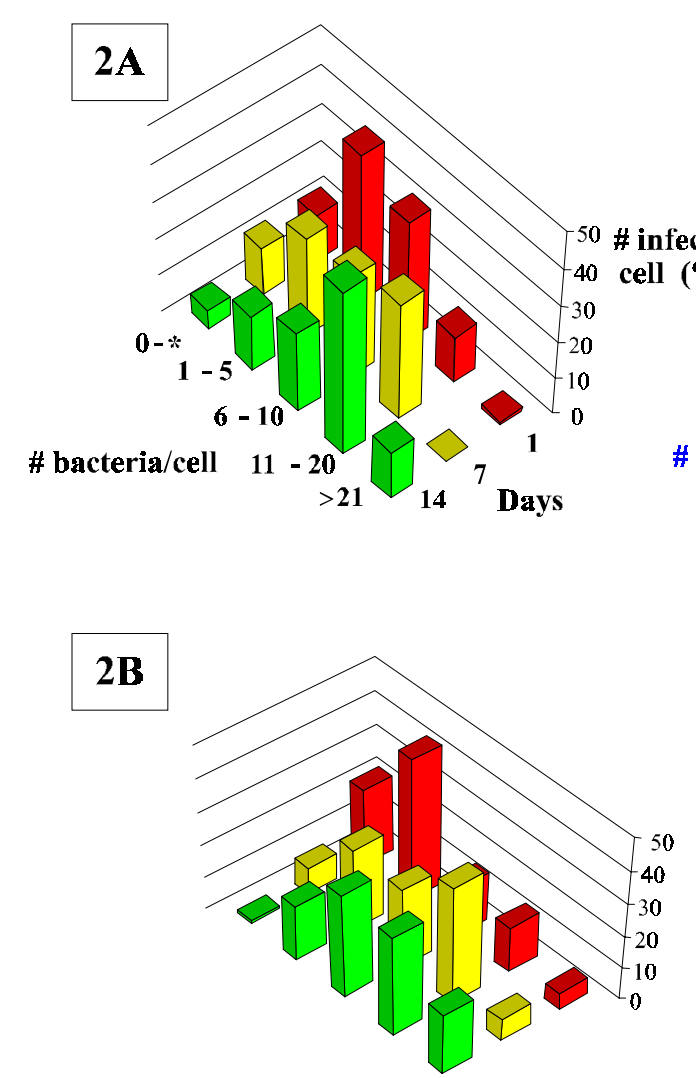

Protoceratium reticulatum
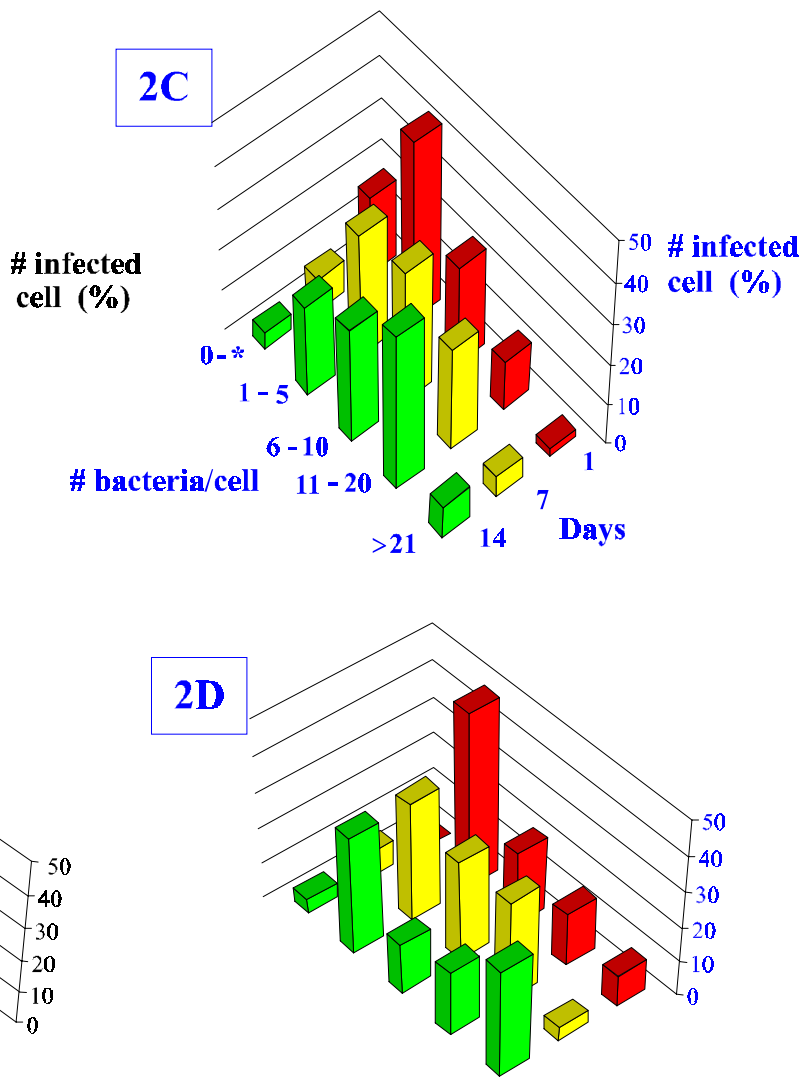

Figure 2

Bacterial multiplication inside dinoflagellates. 2A and 2B, A. catenella; 2C and 2D, P. reticulatum. The number of intracellular bacteria cells was quantified at days 1, 7 and 14 using the CTC method. The number of intracellular bacteria/cell was grouped within ranges as indicated, while the number of infected cells is expressed in percentage (\%). Bacterial burden becomes heavier at the stationary phase of growth curve in both species (day 14). The asterisk indicates that cells may not be infected or that bacteria were undetected by the CTC method

Multiplicación bacteriana dentro de dinoflagelados. 2A y 2B, A. catenella; 2C y 2D, P. reticulatum. El número de bacterias intracelulares por célula fue cuantificado los días 1, 7 y 14 usando el método CTC. El número de bacterias intracelulares por célula fue agrupado dentro de rangos como se indica, mientras que el número de células infectadas se expresa en porcentaje (\%). Hay un mayor número de bacterias por célula en la fase estacionaria de la curva de crecimiento en ambas especies (día 14). El asterisco indica que las células pueden no estar infectadas o que las bacterias no fueron detectadas por el método CTC 

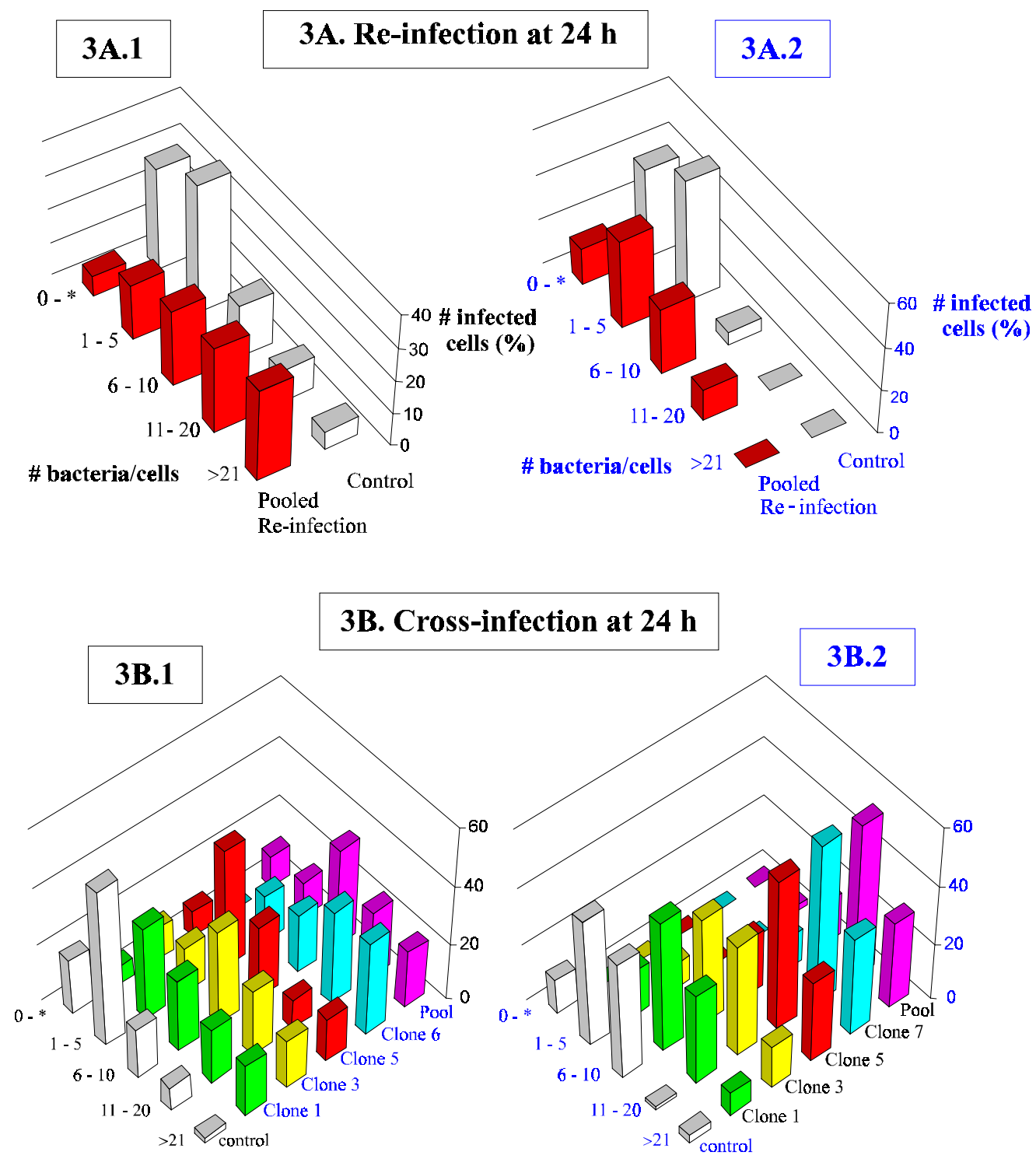

A. catenella $+P$. reticulatum bacterial clones

P. reticulatum $+A$. catenella bacterial clones

Figure 3

Re-infection of dinoflagellates with isolated bacteria. 3A.1, A. catenella; 3A.2, P. reticulatum. Cells were re-infected with their own intracellular bacteria, individually and pooled clones, and evaluated $24 \mathrm{~h}$ after co-cultivation (3A). Isolated bacteria from $A$. catenella were used to cross-infect, individually and pooled clones, $P$. reticulatum (3B.1) and vice-versa (3B.2)

Re-infección de dinoflagelados con bacterias aisladas. 3A.1, A. catenella; 3A.2, P. reticulatum. Las células fueron re-infectadas con sus propias bacterias intracelulares en forma individual o agrupadas, y evaluadas 24 h después de la co-incubación (3A). Bacterias aisladas desde A. catenella se usaron para infectar, individualmente o en grupos a células de P. reticulatum (3B.1) y vice-versa (3B.2) 
sodium nitrate. The sixth tube was supplemented with 5 $\mu \mathrm{M}$ sodium phosphate and $100 \mu \mathrm{M}$ of sodium nitrate, and the seventh tube with $20 \mu \mathrm{M}$ of sodium phosphate and $300 \mu \mathrm{M}$ of sodium nitrate. All cultures were maintained as described above. At days 1, 7 and 14, 3 $\mathrm{ml}$ samples were concentrated by centrifugation (1500 rpm x 20 minutes), and the cell pellet carefully resuspended by tapping the tube. Cells were fixed with glutaraldehyde $(2 \% \mathrm{v} / \mathrm{v})$ final concentration) for 15 minutes at $4^{\circ} \mathrm{C}$ in dim light. After removing the fixative, samples were processed with CTC as described above. Nitrate and phosphate concentrations were used as reported by Flynn et al. (1995). Similar experiments were performed using Protoceratium reticulatum. Cells from both experiments were evaluated by epifluorescence microscopy and confocal microscope as above.

\section{Results}

\section{Time-course multiplication of intracellular bacteria}

Using the CTC staining technique method, we followed intracellular bacterial multiplication inside Alexandrium catenella qualitative (Figs. 1A and 1B) and quantitative (Figs. 2A and 2B) respectively. A. catenella analyzed during the first day of culture (logarithmic phase) suffered a light bacterial infection (Fig. 1A, group 0 and 1-5 bacteria/cell of Figs. 2A and 2B), although, some cells with heavy infection were also observed at this growth phase. After 14 days when the culture was at stationary phase, significantly more $A$. catenella cells had heavy bacterial infection (Fig. 1B, group >21 bacteria/cell on day 14 of Figs. 2A and 2B) as compared to those with less bacteria per cell. This result suggests that intracellular bacteria increases in number inside the dinoflagellate cells.

Similarly, Protoceratium reticulatum cells were analyzed and both light and heavy infection were observed at day 1 compared to day 14 as shown in group $>21$ of Figs. 2C and 2D. Moreover, as shown in Fig. 1D from the stationary phase, heavy infection is not present in the whole cell and seems more restricted to specific intracellular sites (Fig. 1D, arrow doubleheader), a situation which is not observed in Alexandrium catenella.

As observed in Figs. 2A and 2B for Alexandrium catenella and Figs. 2C and 2D for Protoceratium reticulatum, samples from days 1 have more cells with none or light infection than samples from days 7 and 14 . On the other hand, cells had a higher bacteria/cell ratio at day 14 than at day 7 . This experiment was repeated and similar bacterial multiplication pattern was obtained as observed in Fig. 2B.

\section{Infection of $A$. catenella and $P$. reticulatum cells with bacteria isolated from dinoflagellates}

Results indicate that isolated bacterial clones from Alexandrium catenella are capable of re-infecting the same organisms from which they were isolated. As observed in Fig. 3A.1, there are considerably more intracellular bacteria in the cells incubated with the pooled bacteria than in cells from the control culture after 24 h of co-incubation. A number of cells with high bacterial infection were also observed in Protoceratium reticulatum as shown in Fig. 3A.2. However, the number of cells with heavy bacterial infection was not as higher as those observed for A. catenella.

The results show that bacteria isolated from Alexandrium catenella (individually or pooled) are capable of infecting Protoceratium reticulatum cells (cross-infection) as observed in Fig. 3B.1. However, not all bacterial clones appear to be as equally infectious, being clone 6 the most infective. Similarly, bacterial cells isolated from $P$. reticulatum are able to infect $A$. catenella cells (Fig. 3B.2). Again, some bacterial clones are more infectious than others since the number of bacteria per cell is not the same for each bacterial clone.

\section{Intracellular bacterial multiplication under different conditions}

Among chemicals reported to have an effect on Alexandrium catenella cells nitrates and phosphates (Granelli et al. 1998), although their effects on cell toxicity appears to be species-specific. Our results indicate that these chemicals have a measurable effect on intracellular bacteria multiplication. When $A$. catenella was grown in a medium supplemented with sodium nitrate and sodium phosphate, it appears to have stimulated intracellular bacterial division by increasing the number of highly infected cells just at day 1 as compared to the control (Fig. 4A.1) for A. catenella and Fig. 4B.1 for Protoceratium reticulatum. However, the results suggest that the maximum bacterial multiplication wave occurs at day 7 for $A$. catenella (Fig. 4A.2) and at day 14 for P. reticulatum (Fig. 4B.3). When these chemicals were added individually or mixed, at two different concentrations, they did not produce a significant change; rather bacterial multiplication was very similar in all combinations tested after 7 and 14 days but not at day 1 . However, with all the combinations tested, at all the times, bacterial multiplication was always greater in the supplemented medium than in the control cultures. 
Alexandrium catenella

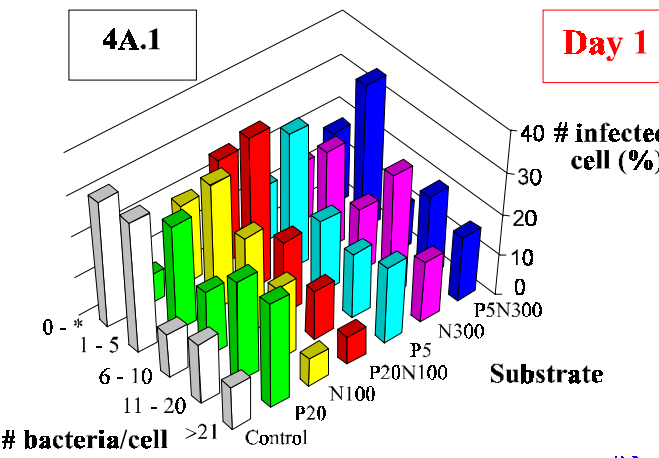

\section{Protoceratium reticulatum}

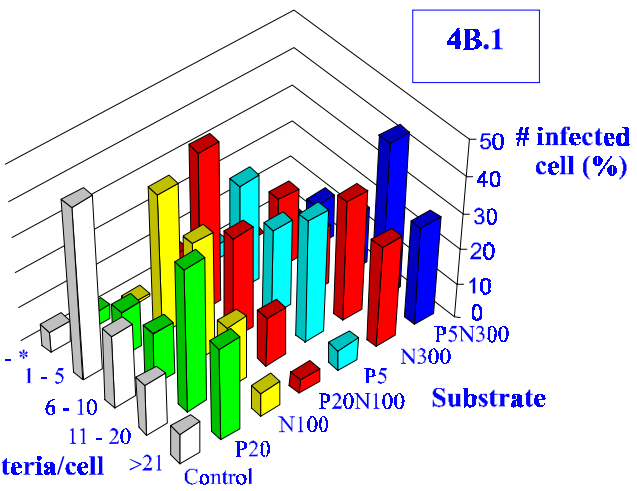

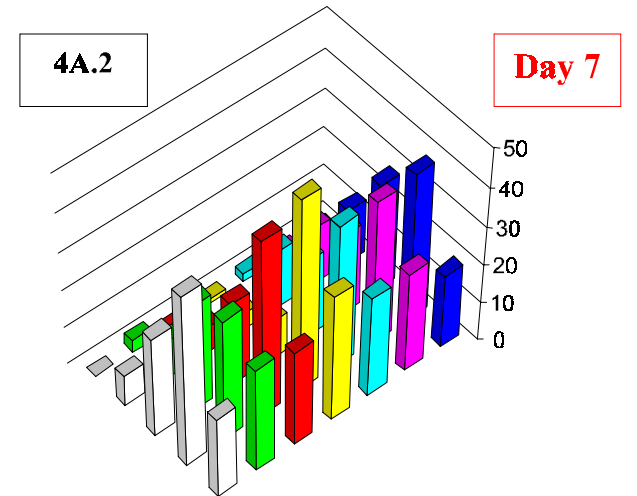
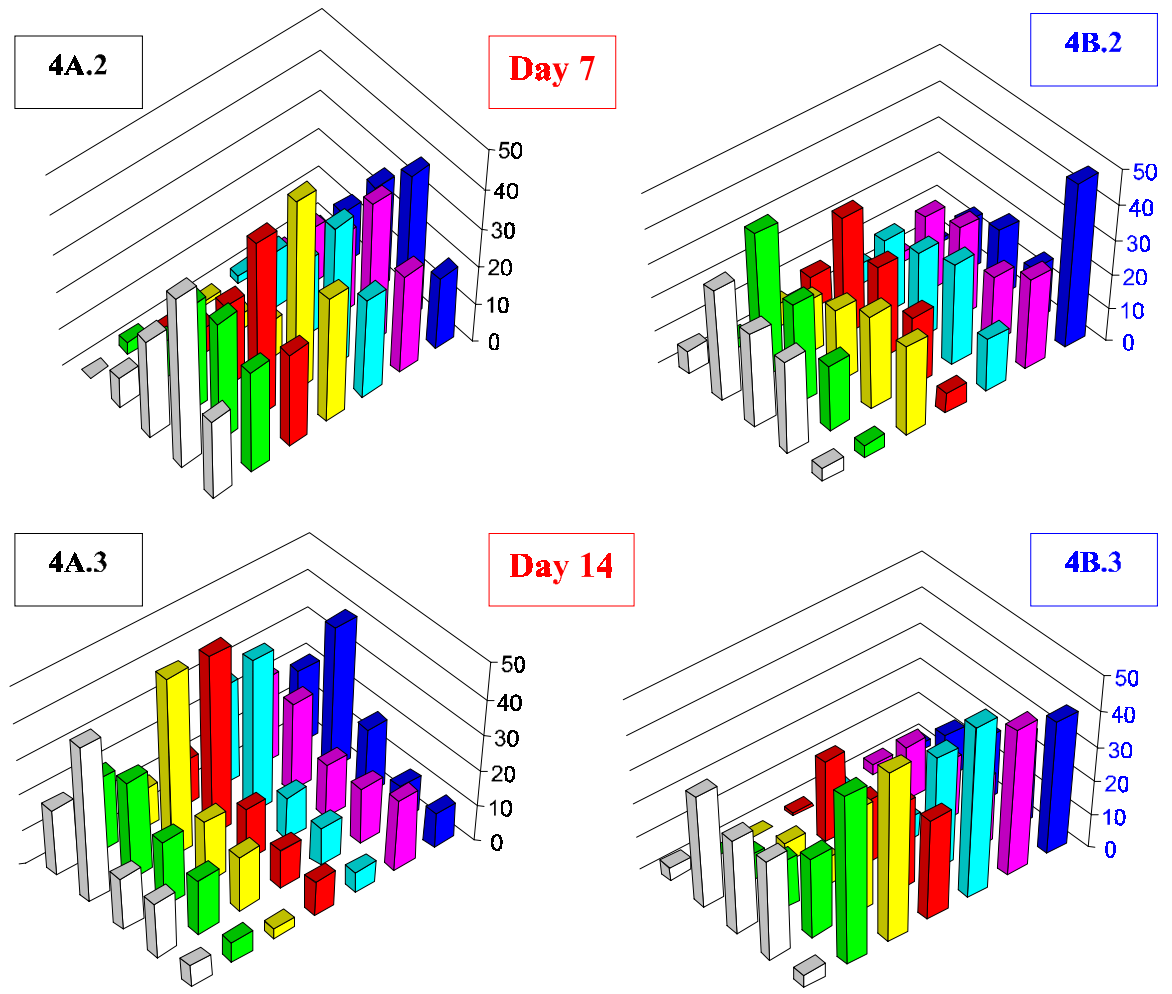

Figure 4

Behavior of intracellular bacterial multiplication under different culture conditions. 4A, A. catenella; 4B, $P$. reticulatum. Cells were grown in medium supplemented with sodium phosphate $(P)$ and sodium nitrate $(\mathrm{N})$ as follows: $\mathbf{P 2 0}(20 \mu \mathrm{M})$, N100 (100 $\mu \mathrm{M})$, P20N100 (20 and $100 \mu \mathrm{M})$, P5 $(5 \mu \mathrm{M})$, N300 (300 $\mu \mathrm{M})$ and P5N300 (5 and $300 \mu \mathrm{M})$. A sample of each culture was taken at days 1, 7 and 14 after innoculation

Comportamiento de la multiplicación bacteriana intracelular en diferentes condiciones de cultivo. 4A, A. catenella; 4B, P. reticulatum.

Las células fueron cultivadas en medio suplementado con fosfato de sodio (P) y nitrato de sodio (N) como sigue: P20 (20 $\mu \mathrm{M})$,

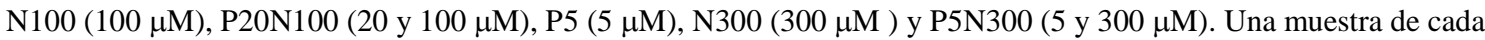
cultivo fue tomada los días 1,7 y 14 después de la inoculación inicial 


\section{Discussion}

Although the presence of bacteria inside dinoflagellate cells from different species has been reported (Silva (1962, Franca et al. 1995; Kodama et al. 1996; Gallacher et al. 1997; Babinchak et al. 1998; Brinkmeyer et al. 2000; Córdova et al. 2001; Lewis et al., 2001) it is unclear how these intracellular bacteria interact with their host dinoflagellate cell. Furthermore, very little is known regarding the behavior, metabolism as well as the biological significance of these intracellular bacteria.

Recently, electron microscopic pictures of Alexandrium catenella showed that intracellular bacteria effectively are dividing (Córdova et al. 2001; Töbe et al. 2003) and to further confirm that the reported intracellular bacteria were alive, it was important to demonstrate that they could multiply inside the dinoflagellate host cell. Results from this study show that there is a bacterial multiplication inside A. catenella and Protoceratium reticulatum. Dinoflagellate cells heavily infected with intracellular bacteria were found as shown in Fig. 1. Moreover, Fig. 1 shows that the cells are not equally infected. This observation was confirmed with results presented in Fig. 2 which shows that the dinoflagellate cell population undergoes a differential bacterial multiplication pattern, a phenomenon detected in both dinoflagellates analyzed here. This bacterial multiplication pattern seems to generate a bacterial division wave, phenomenom that we have termed "bloom inside the bloom", an event that predominantly occurs as the dinoflagellate cultures get older. Nevertheless, it is still necessary to elucidate whether this heavy bacterial infection is a result of intracellular bacteria multiplication or the result of a combination with some bacterial re-infection from older lyzed cells with heavy bacterial infection. Furthermore, the significance of non infected cells detected at all the times suggests that these dinoflagellates could become cysts, since cysts should not present intracellular bacteria.

To demonstrate the ability of bacteria to infect and divide inside the dinoflagellate, re-infection experiments were performed. Results shown in Fig. 3A, suggest that bacteria were capable of re-infecting the cells from which they were isolated. The dinoflagellate cells are capable of supporting higher number of intracellular bacteria apparently without affecting their viability. However, it was noted that those cells with higher bacterial load seem to be more fragile for example, to the pressure generated by the cover slip during sample analysis under the microscope (breaking and reducing its number) and less CTC stain in Fig. 1B (background fluorescent figuring the cell shape) as compared to cell CTC background in Fig. 1A. The experiments also suggest that bacterial infection is an active process, wich could be mediated by specific phagocytic receptors as it has been shown for other models (Wright \& Silverstein 1983) or by endocytic pathways (Helenius \& Mark 1982). Furthermore, these results indicate that isolated bacteria do not loose their capacity to recognize and infect again the dinoflagellates (Figs. 3A.1 and 3A2); they may also infect other dinoflagellates in nature as they have done in vitro (Figs. 3B.1 and 3B2). Since some intracellular bacteria are producers of toxins of the paralytic complex (Gallacher et al. 1997; Córdova et al. 2001), and bacteria can best resist harsh environmental conditions than dinoflagellate motile forms (vegetative cell), it is possible that they play a role in the red tides dissemination because they can also be transported in the ship ballast water and infect the non-toxic dinoflagellates resident in a geographic areas without previous Harmful Algal Blooms (HABs) episodes (Vaulot et al. 2003). This idea should be considered complementary to that proposed by Hallegraeff and Bolch (1992) on dispersion of cyst HABs by ship ballast water. However, experimental evidence will be necessary to confirm this hypothesis.

Individually isolated bacterial clones from one species were used to determine whether they were capable to re-infecting the dinoflagellate from which they were isolated. As shown in Fig. 3A, individual and pooled clones from either dinoflagellates were capable of this. The same bacterial clones were able to infect a different dinoflagellate (cross-infection) as shown in Fig. 3B, displaying different degrees of infectiousness as observed for each bacterial clone. In both cases, the percentage of infected cells (pool) was not higher than those obtained individually. This result suggests that bacterial clones may use similar receptors to infect the cell (Simon et al. 2002).

Chemicals have been reported to affect blooms as well as dinoflagellate toxin production in different ways. Among those chemicals, nitrate and phosphate were shown to have an effect on dinoflagellates (Graneli et al. 1998). We have shown here that these chemicals also affect the intracellular bacterial multiplication observed in both dinoflagellates (Figs. 4A and 4B). It appears that phosphate is more efficient in promoting bacterial division than nitrate.

It has been suggested that dinoflagellates produce substances towards mutual stimulation with bacteria creating a cytoplasmic environment or the phycosphere (Bell \& Mitchell 1972). The ability of nitrate and phosphate to stimulate bacterial division suggests that these chemicals could participate in the modulation of 
the phycosphere. It sppears that live bacteria aggregate (inside or close) to the phycosphere as suggested by observing clumped bacteria in Fig. 1B.1 (double arrowhead), since it is expected that bacterial clumps should otherwise spread out by the pressure generated when the coverslip is on place before microscopic observation.

Considering that some intracellular bacteria are capable of toxins production, one could argue that intracellular bacterial multiplication, which is heavier at stationary phase as shown in this work, may be a reason why dinoflagellates are more toxic at this phase of growth (Parkhill \& Cembella 1999). Also, the observation that heavily infected cells appear more fragile than less infected cells, could suggest that intracellular bacteria, in conjunction with other factors (internal and external) may participate in bloom termination.

Finally, based on this work we propose the hypothesis that the interaction between intracellular bacteria and dinoflagellate is bimodal as shown in Fig. 5. At the beginning, the interaction is mutualistic since dinoflagellate physiology (as deduced by CTC staining still normal) as the intracellular bacteria. As growth proceeds, the interaction becomes parasitic, thus intracellular bacteria multiplies beyond control (bloom inside the bloom) triggered by internal and external factors and causing the dinoflagellate dead.
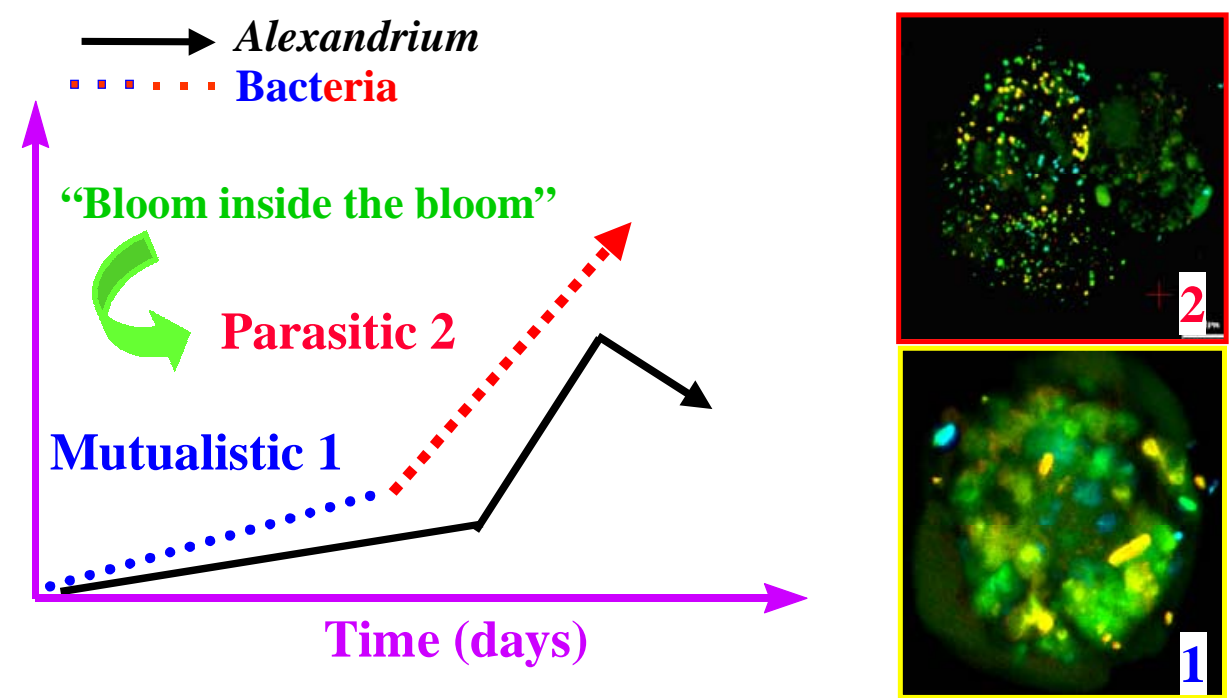

Figure 5

Interaction model between intracellular bacteria and $A$. catenella. Different intracellular bacteria species are observed in photo 1 as deduced by their shapes with CTC staining. The dinoflagellate cell morphology is also highlighted by CTC stain, indicating that $A$. catenella cell is not affected by intracellular bacteria. This stage is considered a mutualistic relationship (blue dotted line). As the culture gets older, the number of intracellular bacteria increases as observed in photo 2. However, it seems that only one or two bacterial species multiplied. The CTC staining is bright indicating that those bacteria are healthy, but not the CTC staining of $A$. catenella cells whose fluorescence is more pale as compared to that of photo 1 . This stage is considered parasitic (red line)

Modelo de interacción entre las bacterias intracelulares y A. catenella. Diferentes especies de bacterias intracelulares se observan en la foto 1 , lo cual es deducido de sus formas con la coloración CTC. La morfología de la célula del dinoflagelado también es observada por la coloración CTC, indicando que la célula de A. catenella no es afectada por las bacterias intracelulares. Este período se considera de relación mutualista (línea punteada azul). A medida que el cultivo se envejece, el número de bacterias intracelulares aumenta como se observa en la foto 2. Sin embargo, pareciera que sólo 1 o 2 especies de bacterias intracelulares se multiplicaron. La coloración CTC es brillante indicando que esas bacterias están saludables, pero no así la coloración de las células de $A$. catenella cuya fluorescencia es más opaca que aquella observada en la foto 1 . Este periodo se considera como parasitario (línea roja) 


\section{Acknowledgements}

We would like to thanks Dr. Elizabeth Smith of FRS Marine Laboratory, Aberdeen, Scotland, for her review and suggestions on this manuscript. This work was supported by the Organization for the Prohibition of Chemical Weapons and Proyecto Marea Roja FONDEF MR02I1003.

\section{Literature cited}

Bates SS, DJ Douglas, GJ Doucette GJ \& C Léger C. 1995. Enhancement of domoic acid production by reintroducing bacteria to axenic cultures of the diatom Pseudo-nitzschia multiseries. Natural Toxins, 3: 428-435.

Babinchak JA, ER McGovern \& GJ Doucette. 1998. Isolation and characterization of the bacterial flora associated with PSP-related dinoflagellates species. In: Reguera B, J Blanco, ML Fernández \& T Wyatt. (eds), Harmful Algae, pp. 410-413. Xunta de Galicia and IOCUNESCO, Grafisant, Spain.

Bechemin C, D Grzebyk, F Hachame, C Hummert \& S Maestrini. 1999. Effect of different nitrogen/phosphorus nutrient ratios on the toxin content in Alexandrium minutum. Aquatic Microbial Ecology 20: 157-165.

Bell WH \& R Mitchell. 1972. Chemotactic and growth responses of marine bacteria to algal extracellular products. The Biological Bulletin 143: 265-277.

Brinkmeyer, R, M Rappé, S Gallacher \& LK Medlin. 2000. Toxic dinoflagellates and their associated bacteria: development of clade (Roseobacter and Alteromonas) and taxon-specific oligonucleotide probes to study bacterial/toxic algal interactions. European Journal of Phycology 35: 315-330

Biegala IC, G Kennaway, E Alverca, JF Lennon, D Vaulot \& $\mathbf{N}$ Simon. 2002. Identification of bacteria associated with dinoflagellates (Dinophyceae) Alexandrium spp. using tyramide signal, amplification-fluorescent in situ hybridization and confocal microscopy. Journal of Phycology 38: 404-411.

Córdova JL, L Cárdenas, L Cárdenas \& A Yudelevich. 2001. Multiple bacterial infection of Alexandrium catenella (Dinophyceae). Journal Plankton Research 24: $1-8$

Doucette GJ., M Kodama, S Franca \& S Gallacher. 1998. Bacterial interactions with Harmful Algal Bloom Species: Bloom Ecology, Toxigenesis, and Cytology. In: Anderson DM, AD Cembella \& GM Hallegraeff (eds). Physiological Ecology of Harmful Algal Blooms, pp. 618-648. NATO ASI Series Vol. G41. Springer Verlag, Heidelburg.
Franca S, S Viegas, V Mascarenhas, L Pinto \& GJ Doucette. 1995. Prokaryotes in association with a toxic Alexandrium lusitanicum in culture. In: Lassus P, G Arzul, E Erard, P Gentien \& C Marcaillou (eds). Harmful Marine Algal Blooms, pp. 45-51. Lavoisier, Intercep Ltd.

Flynn KJ, JM Franco, P Fernández, B Reguera, M Zapata, G Wood \& KJ Flynn. 1994. Changes in toxin content, biomass and pigments of the dinoflagellate Alexandrium minutum during nitrogen refeeding and growth into nitrogen or phosphorus stress. Marine Ecology Progress Series 111: 99-109.

Flynn K, JM Franco, P Fernández, B Reguera, M Zapata \& KJ Flynn. 1995. Nitrogen and phosphorus limitation in cultured Alexandrium minitum Halim does not promote toxin production. In: Lassus P, G Arzul, E Erard, P Gentien \& C Marcallou. (eds). Harmful Marine Algal Blooms, pp. 439-444. Lavoisier, Intercep Ltd.

Gallacher S, KJ Flynn, JM Franco, EE Brueggemann \& HB Hines. 1997. Evidence for production of paralytic shellfish toxins by bacteria associated with Alexandrium spp. (Dinophyta) in culture. Application and Environmental Microbiology 63: 239-245.

Gallacher S \& EA Smith. 1999. Bacteria and paralytic shellfish toxins. Protist 150: 245-255.

Granelli E, N Johansson \& R Panosso. 1998. Cellular toxin contents in relation to nutrient conditions for different groups of phycotoxins. In: Reguera B, J Blanco, ML Fernández \& T Wyatt. (eds). Harmful Algae, pp. 321-323. Xunta de Galicia and IOC of UNESCO, Grafisant, Spain.

Guillard R. 1975. Culture of phytoplankton for feeding marine invertebrates. In: Smith WL \& MH Chanley (eds), Culture of marine invertebrates animals, pp. 29-60. Plenum Publishing Corporation, New York.

Hallegraeff GM \& CJ Bolch. 1992. Transport of diatom and dinoflagellate resting spores in ship's ballast water: Implications for plankton biogeography and aquaculture. Journal Plankton Research 14: 1067-1084.

Helenius A \& M Marsh. 1982. Endocytosis of enveloped animal viruses. Ciba Foundation Symposium, pp. 92: 5676.

Kodama M, T Ogata \& S Sato. 1988. Bacterial production of saxitoxin. Agriculture Biological Chemistry 52: 10751077.

Kodama M, S Sakamoto \& K Koike. 1996. Symbiosis of bacteria in Alexandrium tamarense. In: Yasumoto T, Y Oshima \& Y Fukuyo (eds), Harmful and Toxic Algal Blooms, pp. 351-354. Intergovernmental Oceanographic Commission of UNESCO. 
Kotaki Y, Y Oshima \& $T$ Yasumoto. 1985. Bacterial transformation of paralytic shellfish toxins. In: Anderson DM, AW White \& DG Baden. (eds). Toxic dinoflagellates, pp. 287-292. Elsevier, Amsterdam.

Lewis J, G Kannaway, S Franca \& E Aleverca. 2000. Bacterial-dinoflagellate interactions investigative microscopy of Alexandrium spp. (Gonyaulacales Dinophyceae). Phycologia 40: 280-285.

Nagai S \& I Imai. 1998. Killing of giant diatom Coscinodiscus wailesii Gran by marine bacterium Alteromonas sp. isolated from the Seto inland sea of Japan. In: Reguera B, J Blanco, ML Fernández \& T Wyatt (eds.). Harmful Algae, pp. 402-405. Xunta de Galicia and IOC of UNESCO. Grafisant, Spain.

Parkhill J \& AD Cembella. 1999. Effects of salinity, light and inorganic nitrogen on growth and toxigenicity of marine dinoflagellate Alexandrium tamarensis from northeastern Canada. Journal Plankton Research 21: 939955.

Sawayama S, Y Sako \& Y Ishida. 1993. New inhibitor for mating reaction of Alexandrium catenella produced by marine Alteromonas sp. Nippon Suisan Gakkaishi 59: 291294.

Silva ES. 1962. Some observations on marine dinoflagellate cultures. I. Prorocentrum micans Ehr. and Gymnodinium spinifera (Clap \& Lach.) dies., Gonyaulax tamarensis Leb., and Peridinium trochoideum (Stein) Lemm. Notas de Estudios del Instituto de Biologia Marina 2: 1-21.

Silva ES. 1982a. Relationship between dinoflagellates and intracellular bacteria. In: Hope HA \& T Levring (eds), Marine Algae in Pharmaceutical Science, 2: 269-288. Walter de Gruyter, Berlin.
Simon N, I Biegala, EA Smith \& D Vaulot. 2002. Kinetics of attachment of phycotoxin-producing bacterial strains to Alexandrium tamarensis (Dinophyceae) Aquatic Microbial Ecology 28: 249-256.

Smith EA, FH Mackintosh, F Grant \& S Gallacher. 2002. Sodium channel blocking (SCB) activity and transformation of paralytic shellfish toxins (PST) by dinoflagellate-associated bacteria. Aquatic Microbial Ecology 29: 1-9.

Tamplin MI. 1990. A bacterial source of tetradotoxins and saxitoxins. In: Hall S \& G Strichartz (eds). Marine toxins; origin, structure and molecular pharmacology. American Chemical Society, pp. 78-85. ACS Symposium Series 418, Washington DC.

Töbe K, JL Córdova \& LM Medlin. 2003 (submitted). Determination of intracellular and extracellular associated bacteria with dinoflagellates of the genus Alexandrium.

Vaulot D, S Colin, N Simon \& I Biegala. 2003 (submitted). Recolonization of axenic cultures of Alexandrium tamarensis (Dinophyceae) by natural populations of coastal bacteria.

Wright SD \& SC Silverstein. 1986. Overview: The function of receptors in phagocitosis. In: Weir DM \& L Herzenberg (eds), Cellular Immunology, pp. 41.1-41.14. Blackwell Scientific Publication, Oxford.

Yoshinaga I, T Kawai \& Y Ishida. 1995. Lysis of Gymnodinium nagasakiense by marine bacteria. In: Lassus P, F Arzul, E Erard, P Gentien \& C Marcaillou (eds), Harmful Marine Algal Blooms. Proceedings of The Sixth International Conference on Toxic Marine Phytoplankton, pp. 687-694. Lavoisier Publishing Inc. 